\title{
The Effectiveness of Role Playing Method for Introducing English Words for Kids in Lignita Kindergarten in Sawahlunto
}

\author{
Indra Jaya \\ Department of Early Chidlhood Education \\ Faculty of Education, Universitas Negeri Padang \\ Padang, Indonesia \\ indrajaya.pgpaudfipunp@gmail.com
}

\begin{abstract}
The purpose of this research is to find out the effect of role play in using English words for young learners in Lignita Kindergarten in Sawahlunto. The design of this research is quantitative, with the type of method is quasy experiment. The result of this research is children on experiment class used role play method are higher than control class that used asking and answering method. Based on the result it know that t-count is bigger than t-table, which shown the significant influence in developing English words in role playing for kids. Then, it can be concluded that role playing method has significant influence in developing English words for kids in Lignita Kindergarten in Sawahlunto.
\end{abstract}

Keywords - children's naturalist intelligence; nature surrounding; kindergarten.

\section{PRELIMINARY}

Kindergarten is one form of early childhood education in unit formal education pathways that organize educational programs for children 5-6 years old. Education has a very important role in childhood, because the development of personality, mental and intellectual attitude shaped this age. The quality of childhood is a mirror of future .

Early childhood education is one of the formal education institutions in the early childhood education path, as regulated in Law No. 20 of 2003 Chapter VI Article 28 [1] suggests the goals of early childhood education are: A coaching effort addressed to children from birth to 6 (six) years old, conducted through the provision of educational stimulate, to help growth and physical and spiritual development in order to have readiness in entering further education.

Early childhood is an individual figure as a sociocultural being undergoing a process of development that is fundamental to later life and possesses certain characteristics. Early childhood is an organism that is a whole physical and spiritual unity with all its structures and biological and psychological devices so that it becomes a unique figure.

Early childhood education is essentially an education that is held with the aim to facilitate the growth and development of children thorough or emphasize the development of all aspects of the child's personality. Therefore, education for kindergarten children needs to provide various activities that can develop various aspects of development that include: cognitive, language, social emotions.

From birth all human beings have the nature as social beings that cannot be separated from the social environment that is by way of interaction and communicate. One of the tools used to communicate is the language, which is a symbol used to unite thoughts and feelings to convey meaning to others.

Language development, in early childhood is at the stage grammar development. At this stage the child begins to develop language, the length of the sentence begins to increase, the utterances produced by the complex, and start using the word plural. The addition and mastery of the word gradually increases along with the progress and development of the child. Therefore, it would be nice if in this period the child is given a new vocabulary to multiply the vocabulary of the child and for the child's readiness to communicate / speak. In giving this vocabulary, the child should also be given an English vocabulary. Remember, English is a world language whose its role is quite important.

Based on the results of observations by researchers in the field, that the lack of variety of methods used by teachers, who had been the teacher only question and answer method with the child and told the child to repeat the vocabulary already mentioned. In addition the lack of creativity of teachers in using methods to develop a child's English vocabulary, so that children are not motivated to learn and remember the vocabulary.

The reason researchers are researching this because the role method is very interesting for children. Because the method is close to the daily activities of children play. This is consistent with the slogan "Playing while learning, learning while playing". Based on opinion Mulyasa [2] Language is a communication medium between humans, and English as a bridge to open access to information around the world. The younger generation is expected to be able to explore even though different nations and tried to know.

Kindergarten age children are in an expressive phase of language development. As expressed by Masitoh, and friends in Aisha [3] that language development aims to enable the child to express the mind through simple language quickly, accurately, communicate effectively, and arouse the child's 
interest to speak Indonesian. This means that the child has expected expressed his wish, his rejection, or his opinion through spoken language. Language development as one of the basic capabilities a child should possess, consisting of several stages of age and developmental characteristics.

The child's English proficiency is influenced by the environment in accordance with Vygotsky's opinion in Mulyasa [2] suggests Children learn through collaborative with adults. While the opinion Woolfolk in Mulyasa [2] Children learn through interaction with teachers or other students. In kindergarten known as conversational, learning the language for children will be easy if it has a good environment and appropriate stimulation.

So, to be able to learn English is required practice pronunciation many times with help by people around. The people around are meant here are families especially the elderly so the child is helped to get to know the vocabulary through the guidance of the environment. Because early childhood is in the mimic stage.

Role-playing is a teaching strategy that belongs to a group of social learning models. This strategy emphasizes the social nature of learning, and considers that cooperative behavior can stimulate students both socially and intellectually.Role playing is one method, where learners are actively involved in playing certain roles. Playing on children is one means to learn. Through fun play activities, the child seeks to investigate and gain experience.

Lunandi [7] states role playing is a form of teaching that is diverted from a book of forms of field practice or practice.Role Playing is a game where players play the role of fictional figures and collaborate to knit together a story. Players choose their characters' actions based on the character's characteristics, and the success of their actions depends on the prescribed and determined system of game rules, as long as they follow the established rules, the players can improvise in the direction and outcome of the game. Santrock [8] states role-playing is a fun activity. A further role play is an activity that a person undertakes to gain pleasure.

From the expert opinion above, it can be concluded that role playing is a fun, interactive method that can make learners actively involved in the game so as to facilitate the child to understand a concept. According to Santrock [8] In the game the child always behaves outside his age, above his usual daily behavior, in a game he is one level above himself, just like the game does. The game is in solid form, as in the focal point of the magnifying glass, all developmental trends; as if the child was trying to jump onto the level where he was used to. The relationship of game to development must be compared to the relationship between teaching and development. Children play activities that behave in the age Vygotsky referred to above is a dramatization where the children do activities - as if he became someone else and perform daily activities in accordance with the role he played. In role playing activities, it can be seen in everyday life. The child acts as if he becomes an adult or someone else who is not his or her own character. Role paying can be focused on daily activities like in school.
According to Hurlock [4] namely: Playing a role is often called a mock game, an active form of play where children through behavior and language are obviously related to matter or situation, as if they have other attributes than they really are.

From the description and based on the expert opinion above, it can be concluded that the role playing method is an activity where the child performs a pretending activity or as if he is in the situation according to the story played and imitate the character of another person with his character.

Before doing any Role playing activities, the teacher must know the steps in the dramatization method. So this method can run smoothly and can achieve the expected goals. This study aims to see the effectiveness of dramatization methods for the introduction of the English language vocabulary for children in Lignita Sawahlunto kindergarten.

\section{METHODS OF RESEARCH}

Based on the problems studied then this research type is experiment with Quasi Experimental research design. The population in this study is Kindergarten which is located in Tanah Lapang Sawahlunto Urban Village. The sampling technique conducted in this research is a purposive sampling technique, that is the technique of determining the sample with certain considerations [9].

Based on the above concept, the group that will be used in this research is group B1 and group B2 where group B2 become experimental class and class B1 become control class. This instrument uses Likert scale for its assessment. According Sugiyono [5] Very Good given a score of 4 (SB), Both given a score of 3 (B), Not Good scored 2 (TB), Very Not Good given score 1 (STB).

The data analysis technique used in this study is to compare the difference of two average values, so that it is done by t-test. But before that, first test the normality and homogeneity test.

Before the data is processed, in order to know the data is normal or not distributed then tested by Liliefors test first. One technique that is often used to test the homogeneity of population variance is to use Bartlett test.

\section{RESULTS AND DISCUSSION}

\section{A. Data Description}

The data described in this study consists of two groups, namely data on the development of the English vocabulary of children using the method of role playing called the experimental group and the results of the development of English vocabulary using the question and answer method called the control group. Description of the data of the ability to calculate the experimental class and control class can be seen in table 1 . 
TABLE 1. DESCRIPTION OF THE DATA BETWEEN ROLE PLAYING AND ASK \& ANSWER METHOD

\begin{tabular}{|l|l|l|}
\hline \multirow{2}{*}{ Variable } & \multicolumn{2}{|c|}{ Methods } \\
\cline { 2 - 3 } & Role Playing Method & Ask And Answer Method \\
\hline $\mathrm{N}$ & 20 & 20 \\
\hline Highest scores & 100 & 85 \\
\hline Lowest scores & 85 & 64 \\
\hline Sum & 1875 & 1503 \\
\hline Average & 93,75 & 75,15 \\
\hline $\mathrm{Sd}$ & 4,18 & 6,32 \\
\hline $\mathrm{Sd}^{2}$ & 17,49 & 40 \\
\hline
\end{tabular}

\section{B. Data Analysis}

To draw conclusions from the results of the study, hypothesis testing using t-test. Before conducting t-test, normality test and homogeneity test on the result of the research are done. Normality Test on the experimental class data and control class data were processed to determine the normality test. In this normality test used Liliefors test as presented in data analysis technique. Normality analyzes in the experimental and control classes are in Appendix 29 and Appendix 30. Based on experimental class normality test and control class obtained the price of $\mathrm{L}_{0}$ and $\mathrm{L}_{\mathrm{t}}$ at the level of real $\alpha 0,05$ for $\mathrm{N} 20$ as in Table 2

TABLE 2. CALCULATING RESULTS OF LILIEFORS TEST ON EXPERIMENTAL CLASS AND CONTROL CLASS.

\begin{tabular}{|l|l|l|l|l|l|l|}
\hline No & Class & $\mathbf{N}$ & $\boldsymbol{\alpha}$ & $\mathbf{L}_{\mathbf{0}}$ & $\mathbf{L}_{\mathbf{t}}$ & Explanation \\
\hline 1 & Experiment & 20 & 0,05 & 0,1592 & 0,190 & Normal \\
\hline 2 & Control & 20 & 0,05 & 0,0922 & 0,190 & Normal \\
\hline
\end{tabular}

Based on Table 2 it can be seen that the experimental class $\mathrm{L}$ value of 0.1592 is smaller than $\mathrm{L}$ table 0.190 for $\alpha 0.05$. Thus the value of the experimental class comes from normally distributed data. For control class obtained $\mathrm{L}_{\text {count }} 0.0922$ is smaller than $\mathrm{L}_{\text {table }} 0.190$ to 0.05 . This means that the control class data also comes from normally distributed data. 2 .

Homogeneity Test as the second test requirement is the homogeneity test using Barltett test. This test aims to determine whether the data comes from a homogeneous group, between the experimental class and the control class. If chi squared counts $<$ chi squared table means data comes from a homogeneous group. This is in accordance with what Syafril [6] proposes that: If the calculation of the count is smaller than the table means that the data comes from a homogeneous group, otherwise if the count is greater than the table then the group is not homogeneous.
TABLE 3. CALCULATING RESULTS OF HOMOGENEITY TEST ON EXPERIMENTAL AND CONTROL CLASS DATA.

\begin{tabular}{|l|l|l|l|l|}
\hline ClasS & $\mathbf{A}$ & $\chi_{\text {hitung }}^{2}$ & $\chi_{\text {tabel }}^{2}$ & conclusion \\
\cline { 1 - 1 } Experiment & \multirow{2}{*}{0,05} & 3,26 & 3,84 & Homogen \\
\cline { 1 - 2 } Control & & & & \\
\hline
\end{tabular}

From Table 3 it appears that the count of the experimental and control class is smaller (count $<$ table), meaning that the experimental and control classes have a homogeneous variance. 3. Hypothesis Testing After normality test and homogeneity test, it is known that the two sample classes are normally distributed and have homogeneous variance. Then it can be continued with hypothesis testing by using t-test technique. Hypothesis test is used to find out whether the hypothesis accepted or rejected with the following conditions: $\alpha 0.05$ means there is a significant difference for the value of the storytelling ability. If $t_{\text {count }}$ is smaller or equal to $t_{\text {table }}$ means there is no significant difference in the value of the storytelling ability. If $t_{\text {count }}$ is greater than $t_{\text {table }}$ then for from result of hypothesis test by using $t$-test obtained $t_{\text {count }}$ equal to 9,54. While the $t_{\text {table }}$ for the real level of $\alpha 0.05(5 \%)$ with $\mathrm{df}$ of 38 is $=2.024$. So it can be seen that $t_{\text {count }}$ is bigger than $t_{\text {table }}$ at real level $\alpha 0.05(5 \%)$ that is $9,54>2,024$. Then $\mathrm{H}_{\mathrm{a}}$ can be accepted and $\mathrm{H}_{0}$ is rejected. More can be seen in table 4 below.

TABLE 4. T - TEST HYPOTHESIS

\begin{tabular}{|c|c|c|c|c|c|c|}
\hline No. & Class & $\mathbf{N}$ & $\begin{array}{c}\text { Average } \\
\text { results }\end{array}$ & $\mathbf{t}_{\text {count }}$ & $\begin{array}{c}\mathbf{t}_{\text {tabel }} \\
\alpha \mathbf{0 , 0 5}\end{array}$ & Decission \\
\hline 1 & Experiment & 20 & 92,8 & \multirow[b]{2}{*}{$\mathbf{9 , 5 4}$} & \multirow[b]{2}{*}{2,024} & \multirow[b]{2}{*}{ Ignored $\mathbf{H}_{0}$} \\
\hline 2 & Control & 20 & 80,1 & & & \\
\hline
\end{tabular}

So it can be concluded that there is a significant difference between the results of students' experimental story telling ability (B2) using role playing method with control class (B1) using question and answer method in Lignita Kindergarten in Sawahlunto.

\section{References}

[1] Undang-undang RI Nomor 20 Tahun 2003 Tentang Sistem Pendidikan Nasional.Jakarta: Departemen Pendidikan Nasional.

[2] Mulyasa. 2012. Manajemen PAUD. Bandung: PT RemajaRosdakarya

[3] Aisyah, Siti, dkk. 2009. Pembelajaran Terpadu. Jakarta: Universitas Terbuka

[4] Hurlock, Elizabeth. 1990. Perkembangan Anak Jilid 2, Jakarta : PT Erlangga

[5] Sugiyono. 2012. MetodePenelitianKuantitatif, Kualitatif, dan R \& D (cetakanke 9). Bandung: Alfabeta 
[6] Syafril. 2010. Statistika. Padang: SUKABINA Press

[7] Lunandi. 1980. Pendidikan Orang Dewasa : Sebuah Uraian Praktis untuk Pembimbing, Penatar dan Penyuluh Lapangan. Jakarta : PT Gramedia

[8] Santrock, John W. 2002. Life- Span Development/ Perkembangan Masa Hidup. Jakarta: Erlangga

[9] Arikunto Suharsimi.2012.Dasar-dasar Evaluasi Pendidikan, Jakarta : Bumi Aksara 